\author{
ANNALS OF THE \\ UNIVERSITY OF CRAIOVA
}

Series: $\checkmark$ Biology

$\checkmark$ Horticulture

$\checkmark$ Food products processing technology

$\checkmark$ Environmental engineering

\title{
Vol. XXVI (LXII) - 2021 \\ THE NECESSITY OF RECONSTRUCTION, MODERNIZING AND DEVELOPMENT IN RESPECT TO THE NATIONAL VINE CULTIVATION PATRIMONY AFTER THE AGRARIAN REFORM OF 1921
}

\author{
Popa Aurel \\ ${ }^{1 *}$ Faculty of Horticulture - Craiova, 13 Al.I.Cuza Blvd., tel. 0251414541 \\ *Correspondence author. E-mail: aurelpopa23@yahoo.com
}

Keywords: reform, region, vine kind, sortiment, areas.

\begin{abstract}
The two highly unfortunate yet greatly important events which have rather quickly indeed succeeded one to the other during the former two centuries (that is to say the attack of the phylloxera upon all of the vineyards throughout Europe and consequently in Romania which had been rather shortly afterwards followed by the burst of World War I) have intensely weakened the whole of the until then economically very successful fabric that had been functioning throughout Europe and therefore as well in Romania in what did concern the respective professions of viticulture and wine-making. As a common but most pernicious sideeffect of the above mentioned events the scientific research in regard to these disciplines had to be delayed if not abruptly interrupted. This is why after the war both as money-making professions as well as scientific disciplines the domains of viticulture and wine-making have found themselves forced to cope with a large number of unavoidably occurring great difficulties against which they had to stand and to strive with.

Apart from the destructions and the other various nuisances which had been generated due to the military operations that had been carried on throughout the respective territories of the concerned viticultural regions the baneful consequences caused in its aftermath by the disaster which had been brought in by the phylloxera had also started to gradually reveal themselves until their gravest levels. Among these highly unfortunate consequences let us mention the loss of the uniqueness that had been the definitory feature of the sorts of kinds of vines; obsoleteness had touched the respective and traditionally validated harvest dates; the distinctive wine-making traditional techniques had also come to be useless; unavoidably then the respective features and organoleptic assets formerly held as distinctive by each of these sorts of kinds of vines had come to be diminished and this is how the once well-known and specific personalities of each of the formerly issued wines - which in the past had all of them been duly and rigorously taxonomized by precisely defined types - had come to gradually fade away.

As a direct consequence of this latter phenomenon a large number of kinds of vine have then been brought in Romania but their respective indigenous countries and oeno-climate zones have indeed been offering cultivation conditions which had been obviously different from the ones which do exist in our country. A lot of rough seed beds had thus appeared in Romania which had more or less clandestinely been created by the ones among the producers of the offspring planting material who had been hankering for some too easily gained money - or the most available technique that could enable them to reach for this goal was precisely the intentful multiplying of directly productive hybrids. Due to the agrarian reform that had been enforced in 1921 the viticulturally effective land surfaces which had respectively come to be owned by the newly endowed people not only did keep on decreasing bit by bit but they had
\end{abstract}


been also gradually deprived from the materially embodied technical resources they would have needed in order to appropriately maintain and most successfully exploit their own viticultural plantations. As a matter of fact around 1921 and as well for some further time afterwards in our country the viticultural and wine-making domains had come to be ruled in accordance with four different laws which yet were all simultaneously enforced upon our territory (that is to say the respectively Romanian, Hungarian, Austrian and Russian ones). It was then under these precise local circumstances that the great economical crisis of 19291933 had "made the choice" to supervene.

Should we be fully aware of the effective existence at that time of this whole bunch of difficulties we would indeed be able to better understand and evaluate the actions which had been officially taken immediately after the agrarian reform of 1921 as well as the multiple efforts which had been carried on upon its behalf. These latters have namely concerned the duly required restoration, the most appropriate modernizing and the further development of the national viticultural patrimony (should these taken actions have pertained to the organisational, administrative and legislative processes or either to the scientific research and academic training activities).

\section{INTRODUCTION}

The two great but we already know too well how pernicious events which have also been rather quick to succeed one to the other that is to say the phylloxera's attack and the World War I have intensely shaken out the whole economical scaffolding upon which not only in Romania but throughout Europe itself the vine cultivation and winemaking respective professions had until then been grounded. The scientific activities related to those domains had thus to suffer the most debilitating consequences indeed which could have been created out of these unfortunate yet generally extended circumstances. The most judicious response which could be brought to them was undoubtedly the one of taking some urgent actions through the performance of some continuous efforts in order to effectively realize and restore as it had been before the normal trends which did concern our own production of wines and their consequent trading. Some adequate possibilities ought as well be offered so that within the respective domains of vine cultivation and wine-making the activities of academic training and scientific research should be further developed since without them it would have been impossible to even conceive a plan which could involve the respective reconstruction, modernizing and development of the national patrimony until then owned by the vine cultivation domain.

\section{MATERIAL AND METHOD MADE USE OF}

The goal of the present work has been the one to most accurately describe in their intrinsic dynamics the initiatives taken at that time by the Romanian vine cultivators in view of their success to be achieved in the respectively reconstruction, modernizing and development of the national patrimony once owned by the Romanian vine cultivation domain after the enforcement of the agrarian reform in 1921. For this purpose we have consulted many bibliographical sources which at their times had pin-pointed some: activities pertaining to the organisational and administrative spheres; activities pertaining to the respective spheres of academic training and of scientific research (for example the precise evaluation of the remaining national vine cultivation patrimony, a newly chosen perspective assumed upon the existing vine sorts which did consist on one side in favoring the engrafted noble vine kinds and on the other side in the restrictive until elimination trend to be applied insofar the directly productive hybrids could be concerned, an exact 
knowledge to be acquired of the wine's chemical composition and consequently the defense brought to its natural inner assets and to its genuine quality level, some newly developed scientific interests within the respective domains of micro-biology and wine-making technology). The scientific works and legislative issued norms we have consulted and which do focus upon all of these matters are to be found in their original forms at respectively the Romanian National Archives, the Library of the Romanian Academy, the Library of the Academy of Agricultural and Sylvan Sciences as well as within the libraries of the various Romanian scientific rersearch institutes or within the ones of the other provincial Universities profiled upon the study of agricultural sciences.

\section{OBTAINED RESULTS}

1. Evaluation of the current status held at that time by the national vine cultivation patrimony and the consequent taken actions which did pertain to the organisational and administrative spheres.

Apart from the destructions and the damages which had supervened due to the military operations which had been carried on within the respective territories of the formerly vine cultivated regions the ill-fated yet always progressively developing consequences of the disaster which in respect to that moment had some time ago been caused by the phylloxera attack were keeping on to more clearly reveal themselves. In spite of the fact that geographically speaking the respective territories held by the vine cultivated regions had remained the same as before the phylloxera's attack some of their essential assets had yet been irretrievably lost such as: - the former and most judiciously constituted uniqueness owned by each among the ancient sorts of vine kinds (see Table 1); - the traditionally homologated as well as precise harvest date had thus become obsolete; - the distinct wine-making procedures previously owned by each of the ancient vine kinds had therefore become useless too. As direct suites of these facts the wine itself had come to suffer from all of them through the respective losses of its formerly owned specific inner features and organoleptic empirically attractive assets which until then had aggregated the traditionally acknowledged type-casting of each wine through which its long since well-known personality had until that time been exquisitely expressed.

The very large number of the new vine kinds which had been brought in Romania from a lot of countries as well as from climate zones which were different from the ones within our country and of which the culture requirements, productive and quality aptitudes were also at that moment unknown to us but which had come in anyway through the massive importation of engrafted vine logs - were thus by then placing under question marks the grounds themselves of the formerly applied cultivation methods which until that moment had lasted in the common practice of the domain for centuries long. The situation had also come to be aggravated due to the rather invasive appearance of always more numerous seed bed nurseries and producers of plantable material among whom most of them were simply wishing for some easy gains which they thought they could come to through some irresponsible advertising practices, through the unfortunately welcomed invasion of the directly productive hybrids as well as through many other foul play methods. 
Table 1

Kinds and sorts which had been cultivated within the Romanian vineyards before the phylloxera's attack. Usual closeness range of vine plants aligned in serried ranks/ha. Vine cutting systems and guiding shapes (apud Teodorescu C.I., 1939)

\begin{tabular}{|c|c|c|c|}
\hline Vineyard & Sort & $\begin{array}{l}\text { Closeness } \\
\text { range of } \\
\text { vine plants } \\
\text { (log/ha) }\end{array}$ & $\begin{array}{l}\text { Cutting system and guiding } \\
\text { shape }\end{array}$ \\
\hline Odobeşti & $\begin{array}{c}\text { Galbenă 2/3 } \\
\text { Plăvaie+Poamă } \\
\text { verde+Poamă Pârce }\end{array}$ & $3500-4500$ & \\
\hline $\begin{array}{l}\text { Oreviţa and } \\
\text { Golul Drâncei }\end{array}$ & $\begin{array}{c}\text { Corb (Negru vârtos) } 1 / 3 \\
\text { Seină neagră (Negru } \\
\text { moale } 1 / 3 \\
\text { Berbecel (Aurel) } 1 / 3\end{array}$ & \multirow[b]{2}{*}{7000} & \\
\hline Drăgăşani & $\begin{array}{c}\text { Cârlogancă (Crâmpoşie) } \\
1 / 3 \\
\text { Braghină } 1 / 3 \\
\text { Gordan+Tămâioasă } \\
\text { românească } 1 / 3\end{array}$ & & \\
\hline Cotnari & $\begin{array}{c}\text { Grasă } 1 / 3 \\
\text { Fetească albă } 1 / 3 \\
\text { Frâncušă } 1 / 3 \\
\text { Tămâioasă albă de } \\
\text { Moldova } 1 / 6\end{array}$ & & \\
\hline Dealul Mare & $\begin{array}{c}\text { Gordan } 1 / 3 \\
\text { Băşicată } 1 / 3 \\
\text { Tigvoasă } 1 / 6 \\
\text { Amestec de } \\
\text { Tămâioasă+Coarnă } \\
\text { albă+Verdea } \\
\text { Negru vârtos } 1 / 3 \\
\text { Negru moale } 1 / 3 \\
\text { Coarnă neagră } 1 / 3 \\
\text { Tămâioasă neagră } 1 / 6\end{array}$ & $4000-6000$ & \\
\hline Banat (Miniş) & $\begin{array}{c}\text { Frunză de tei } \\
\text { Cadarcă } \\
\text { Bacator (Rujiţa) } \\
\text { Abat } \\
\text { Fetească albă } \\
\text { Furmint } \\
\text { Mustoasă } \\
\text { Păsărească } \\
\text { (Apro fehér) } \\
\end{array}$ & 9000 & \\
\hline & $\begin{array}{c}\text { Fetească albă } \\
\text { (Leanca)-so to speak }\end{array}$ & & \\
\hline
\end{tabular}




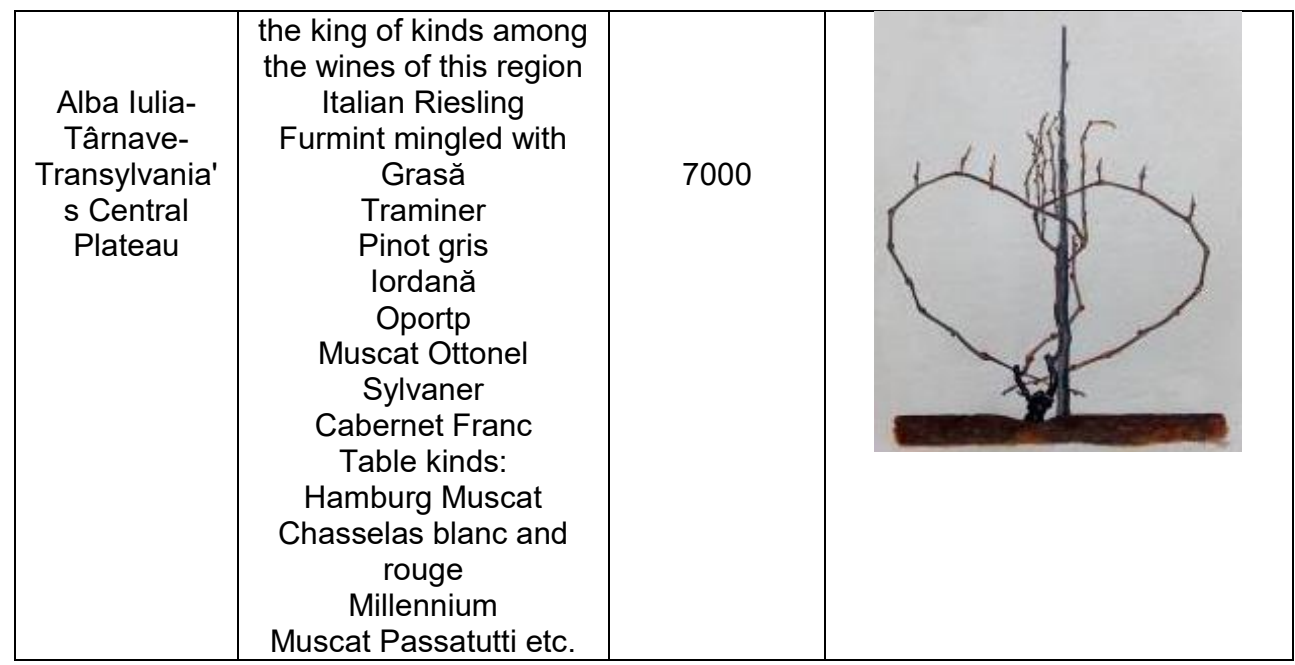

Within the interval going from 1929 till 1933 the whole of the economical life throughout the world has undergone a general crisis which has led to an alike consequently general decrease of the wine consumption. All of the vine cultivating countries Romania included had thus been confronted with a falsely comforting excessive production of wine due to which its usual trading price had fallen and frauds had therefore been hugely amplified. Unfortunately certain measures which had already been initiated in order to diminish the occurring effects of the above mentioned crisis could not be effectively applied (for example the alimentary alcohol ought to have been obtained out of wine only but not any more from cereals or vinegar ought to have been obtained out of the wine issued from directly productive hybrids only but not any more through the pyrogenic process exerted upon wood) (Teodorescu C. Ştefan and coll., 1987).

Table 2 does present the evolution of the vine cultivation patrimony in Romania during this intensely harmful period; from it we could easily draw the conclusion that the directly productive hybrids were keeping on occupying more and more surfaces till the extent of eventually becoming larger than the ones occupied by the noble kinds and ultimately overcoming them.

Table 2

Evolution of the vine cultivation patrimony in Romania (1914-1937)

\begin{tabular}{|c|c|c|c|c|}
\hline \multirow{2}{*}{ Year } & \multirow{2}{*}{$\begin{array}{c}\text { Total surface } \\
\text { (ha) }\end{array}$} & $\begin{array}{c}\text { Engrafted vine } \\
\text { logs }\end{array}$ & $\begin{array}{c}\text { Vine logs } \\
\text { rooted on their } \\
\text { own }\end{array}$ & $\begin{array}{c}\text { Directly } \\
\text { productive } \\
\text { hybrids }\end{array}$ \\
\hline 1914 & 71467 & 31475 & 39992 & - \\
\hline 1924 & 210034 & 104948 & 105086 & - \\
\hline 1927 & 23987 & 107892 & 38222 & 93761 \\
\hline 1933 & 273195 & 123875 & 36435 & 167625 \\
\hline 1937 & 369042 & 120590 & 26118 & 218721 \\
\hline
\end{tabular}

The Agrarian Reform enforced in 1921 has also caused some important transformations to be undergone by the vine cultivation domain (that is to say on one 
side the vine cultivated exploitations did become split into plainly said minimal plots yet on the other side through this enforced trend the economical and social status of the peasants had improved considerably indeed). In order to most judiciously rule over the already existing and by then generalized situation one among the first actions taken had been the one of enforcing the control exerted by the state over all of the private seed bed nurseries which were by then producing plantable material (1922); these institutions have thus become obliged to multiply only the vine kinds which had been previously chosen by the obligându-le să înmulţească numai soiurile stabilite de Ministry of Agriculture (Table 3 ) and their respective number was of 50 (15 for high quality white wines; 9 for white wines destined to a large scale consumption; 8 for high quality red wines; 12 for producing table grapes; 6 destined to be engrafted).

Table 3

Kinds of vine recommended for cultivation after 1921 in Romania

\begin{tabular}{|c|l|}
\hline Productive Direction & \multicolumn{1}{|c|}{ Varieties } \\
\hline High quality white wines & 1.Braghină; 2.Chardonnay; 3.Crâmpoşie; 4.Fetească \\
& albă; 5.Grasă; 6.Furmint; 7.Muscat Frantignan; \\
& 8.Muscat Ottonel; 9.Pinot gris; 10.Riesling; \\
& 11.Sauvignon; 12.Sylvaner; 13.Traminer; \\
& 14.Tămâioasă românescă; 15.Fetească regală \\
\hline White wines destined to a large & 1.Aligote; 2.Băşicată; 3.Frânbcuşă; 4.Galbenă; \\
scale consumption & 5.Gordan; 6.Muscade; 7.Mustoasă; 8.Plăvaie; \\
& 9.Selection carrier \\
\hline Varieties destined to produce & 1.Cabernet Sauvignon; 2.Cadarcă neagră; \\
high quality red wines & 3.Negru vârtos; 4.Pinot noir; 5.Băbească neagră; \\
& 6.Negru moale; 7.Fetească neagră; 8.Bătută neagră \\
\hline Table grapes destined to fresh & 1.Muscat perla de Csaba; 2.Mandelane Angerine; \\
consumption & 3.Lignan; 4.Cgasselas dore; 5.Muscat Hamburg; \\
& 6.Coarnă albă; 7.Coarnă neagră; \\
& 8.Chasselas Napoleon; 9. Asma; 10.Afuz Ali; \\
& 11.Tâţa vacii; 12.Dodrelabi \\
\hline Vine kinds destined to be & 1.Riparia; 2.Riparia Rupestris 3306; 3.Berlandieri 41B \\
engrafted & limitat; 4.Rupestris du Lot; 5.Mourvedrex; \\
& 6. Riparia Rupestris 3309 \\
\hline
\end{tabular}

The trade activity which had concerned the planting material and which until then had been practiced by a lot of unexperienced profanes of our domain had therefore been legally prohibited. All of the existing seed bed nurseries - should these have been owned by the state or either private ones - as well as all of the existing vine cultivation schools have been obliged to found some pure vine plantations made of kinds that only were fruit-bearing ones or if not then destined to be engrafted. Suiting the material endowments or the deliberately chosen purpose of each of these institutions all of them have been obliged to become seriously involved paticipants in demonstrative or either experimental activities. 

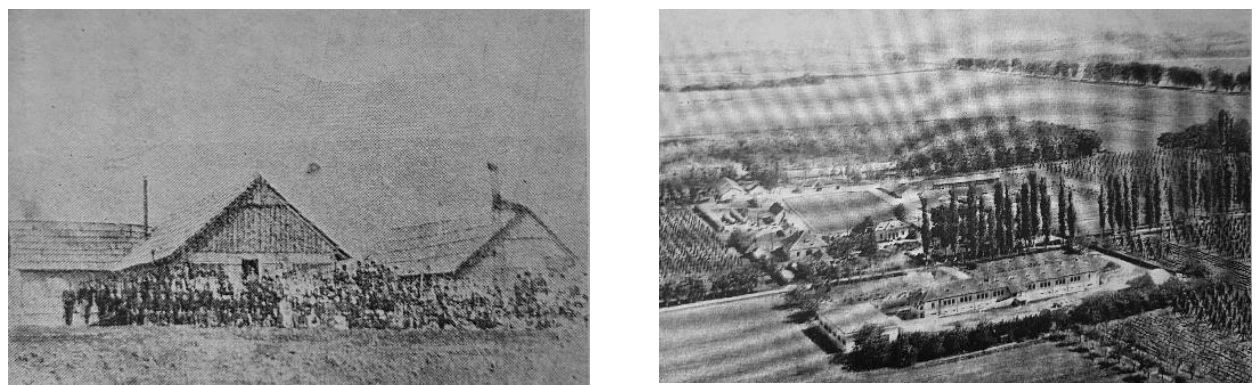

Inauguration of the viticulture seed bed nursery of Drăgăşani (1898)

Survey perspective upon the Viticulture Seed Bed Nursery of Drăgăşani (1898)

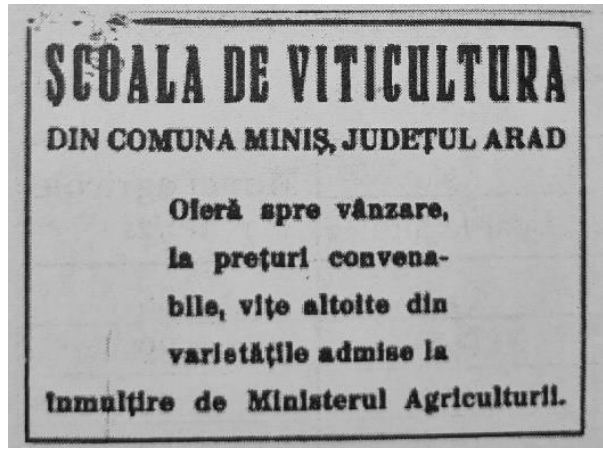

Seed bed nursery at the Viticulture School of Miniş

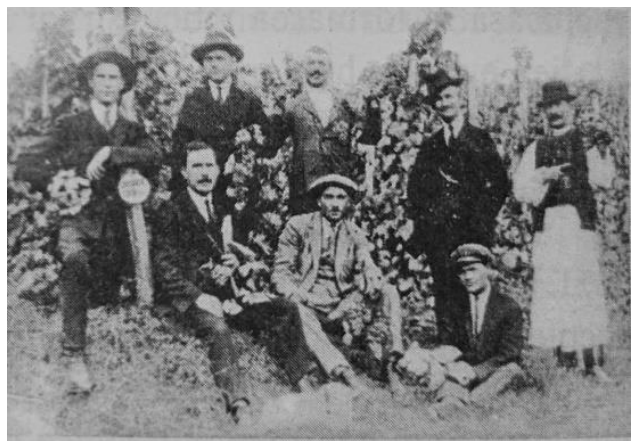

The professors of the Viticulture School of Miniş joined by the seed bed nursery owner Mârza Simion

In 1931 has been constituted the „Association of the Seed Bed Nursery Owners from Romania" the chosen purposes of which have respectively been: to liquidate the importation practices which did involve planting material and subsequently to cover the needed amounts of it from our own Romanian resources; to accurately delimit the most appropriate zones able to suit each among the cultivated vine kinds and to liquidate the existing plantations of directly productive hybrids. The state had by then assumed a very active part in the quality control which was exerted over the multiplying material.

At the Ministry of Agriculture the Direction for Viticulture did elaborate a legislative project through the enforcement of which the pursued aims were to unify the legislation issued on vine cultivation and wine-making throughout the whole territory of Romania as well as to prevent and strive against the committed frauds and falsifications insofar respectively the producing, detaining, circulation and trading of the wines and other alcoholic beverages could be concerned. The above mentioned legislative project had been also accompanied by the adjacent project of its applying regulations which had been elaborated in a most minutious shape since it did as well contain not just the integral text of the officially chosen analysis methods which should have been applied to the wines and other alcoholic beverages but as well a nominal list of the laboratories which had been officially authorized to perform the respective analyses. These methods had been conceived and scientifically verified at the Agronomic Stations of Bucharest and of Cluj. The project had 
eventually become a law which had been enforced in 1927. Its completude as well as the most judicious modality of its elaboration has not at all been ignored by the foreign specialists of the domain who have carefully scrutinized it and therefore much appreciated it by taking it into consideration as being simultaneously and equally rightful and severe.

A specialized service focusing upon the repression of frauds had then been organized the members of which were widely recognized specialists. The greatest effort having then been performed in respect to the analytical control exerted upon the wines had been the one achieved by the Agronomic Station of Bucharest which once integrated within the frame of the R.I.A.R. had afterwards been denominated as the Agronomic Central Station and next as the Chemistry - Oenology Station. Or this newly founded service has indeed succeeded in performing its decisively taken repressive action it did exert upon the attempted frauds and falsifications; its highly efficient activity has brought as its direct and much important consequence the efficiently productive restoration of the Romanian vine cultivation and wine-making normal practices. The above mentioned progress by them achieved at that precise moment in time is related to the success which had then been enjoyed by the organisational cooperation structures then established. As a matter of fact at the highest decisional levels through the main elaborated estimation the conclusion had been drawn that the salvation itself of the Romanian vineyards out of the undergone terrible crisis could have only been achieved through the intermediary of this strategical movement to be applied because no action with the respective purposes of ensuring whatever required technical guidance or then a correct revaluation through some correct trading practices could have been taken unless the cooperative modality should have been chosen and applied. At that time - that is to say after the agrarian reform which had been enforced in 1921 - in our country a densely split surface of about 370000 ha of vine plantations had eventually come to be respectively owned by a number of more than 1200000 families. Most among these little cultivators did effectively own vineyard areas of less than 0,5 ha and from the total surface by then allotted to the engrafted vine logs $16 \%$ only did belong to land estates that had managed to be larger than the above mentioned - and which did really look like a common measure unit - area of 0,5ha (Teodorescu C.I., 1939; 1934; Constantinescu Gherasim, 1939).

In Table 4 we are able to see an edifying example of this crumbling phenomenon which did concern the vine plantations once owned by the Domeniul Coroanei [Crown's Domain] in the Dealul Robului realm from the Segarcea region. Until the Agrarian Reform of 1921 the vineyards from the realm of Dealul RobuluiSegarcea the surface of which had been of 1489 acres had pertained to the Crown's Domain. As a direct result of the legislative real estate endowment procedure which had been enforced for the benefit of a number of 1316 peasant local inhabitants the same number of real estate ownerships has been thus created; each of them did hold a vine cultivated area of about 1,13 acres. 
Table 4

Viticultural surfaces which had existed in Segarcea (namely at the Dealul Robului vineyards) before and after the Agrarian Reform of 1921 (apud Constantin Berger, 1946)

\begin{tabular}{|c|c|c|c|}
\hline Commune & $\begin{array}{c}\text { Number of } \\
\text { inhabitants }\end{array}$ & $\begin{array}{c}\text { Ancient vine plantations } \\
\text { established since 1884 taken } \\
\text { care for through a farming } \\
\text { lease paid in nature from the } \\
\text { Domeniul Coroanei and } \\
\text { which later had been } \\
\text { attributed to the peasants in } \\
1921 \text { (in acres) }\end{array}$ & \\
from 1921 on (ha) \\
\hline Bârca & 8 & 6,103 & \\
\hline Întorsura & 5 & 2,800 & 2,360 \\
\hline Siliştea Crucii & 3 & 2,103 & 1,508 \\
\hline Amzuleşti & 7 & 4,427 & 2,402 \\
\hline Goicea Mare & 3 & 1,066 & 0,526 \\
\hline Craiova & 5 & 11,170 & 3,651 \\
\hline Giurgiţa & 58 & 48,128 & 18,975 \\
\hline Portăreşti & 23 & 23,774 & 9,931 \\
\hline lonele & 14 & 9,723 & 3,736 \\
\hline Urzica & 63 & 50,00 & 29,096 \\
\hline Lipovu & 242 & 261,937 & 47,683 \\
\hline Cerătu & 220 & 193,663 & 93,188 \\
\hline Malaica & 26 & 24,162 & 12,454 \\
\hline Segarcea & 640 & 850,425 & 230,072 \\
\hline TOTAL & 1316 & $1489,481^{*}$ & 456,746 \\
\hline TOTAL & & & 1201,4910 \\
\hline REALMS & & & \\
\hline BaA & & \\
\hline
\end{tabular}

${ }^{*}$ Before 1921 the surface of 1489,481 acres had been owned by Domeniul Coroanei Segarcea

Yet the most interesting issues to them related are the ones that the vine plantations which had been made use of throughout this legislative process had in their agricultural reality been founded 30 till 40 years before and that the phylloxera attack had as a matter of fact already exhausted them once; their necessary restoration after it had thus been realized by their substitution with quite a puzzle of vine kinds a lot among which could present insofar quality could be concerned only scarce credentials or which either should have been rather unsuitable in respect to the climate circumstances usually offered by the Segarcea region. After 1921456 more ha have been planted into the total surface of which are as well included the 300 ha that the Domeniul Coroanei vine cultivation firm has eventually also planted within a nearby situated area. 

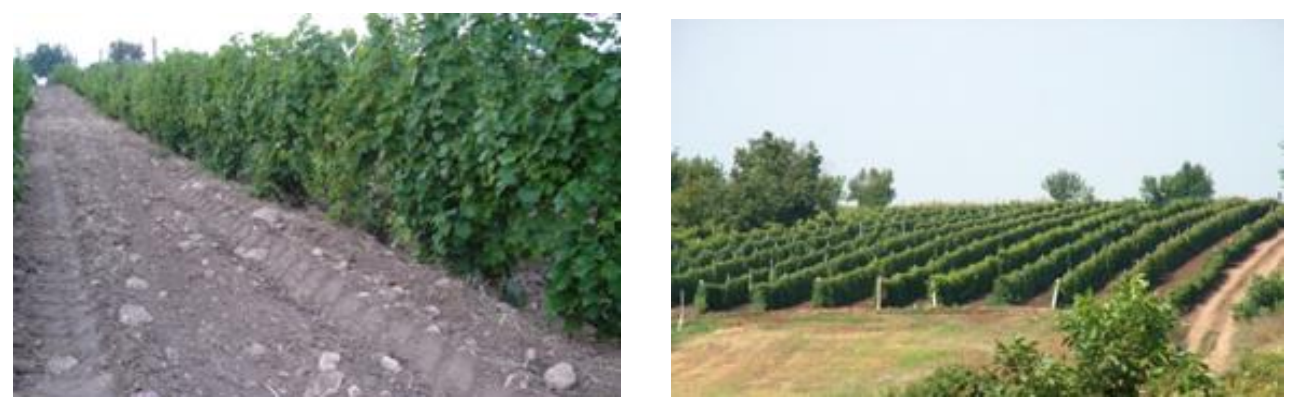

Classical vine plantation situated upon the plot of Dealul Robului ("Bondsman Hill") in Segarcea

However the newly endowed 1316 peasant real estate owners had as well the chance to benefit from the rather opportune fact that their respectively obtained first ever own grape harvests could all at once be proposed for purchase by the press house of the Domeniul Coroanei firm which on its turn used to be very well endowed with the most appropriate technical wine-making tools. Yet as the vineyard real estates did keep going straight on to be further crumbled the consequently obtained wines did present no features at all in respect to homogeneity, oenologic health status or hold quality level which could indeed have made them that much apt so that they could compete against the wines bearing a foreign origin. Most among the newly endowed vineyard owners did not as well own what they necessarily would have needed that is to say press houses, wine cellars, appropriate vases to deposit it in or the technical tools through which they could have suitably processed the harvested grapes and properly ensure the wine's conditioning. As a direct consequence they had become eventually obliged to sell the grapes harvests or their resulted wines as quickly as they could and for trifle prices which could in no way cover the hard labour that had been carried on throughout the year in order to obtain them. There were thus some opportune indeed actions to be taken by the little producers like the ones to reunite themselves within a vine cultivation cooperative so that they could build their own wine-making locations, to adequately endow them with the most appropriate technical devices and then to call in for some qualified specialists of the domain. As a matter of fact the cooperative form could even bring some financial advantages since under this assumed legal form it could be granted cheaper lawns. It could as well - and it did quite so - restore for the wines issued from the small property owners their former orientation towards the aim of a high quality level and so the ancient prestige that the Romanian vineyards had been granted with in the past could more or less be rehabilitated. At that moment there had however been only a few such production units grouped under the denomination of National Federation of Wine-making cooperatives from Romania and they have since then been duly mentioned (Popa A., 2014; Popa A.,Dicu Cornel, 2010). Among them were functioning the ones from Cotnari, Nicoreşti, Topoloveni, Miniş, Odobeşti, Drăgăşani, Diosig, Cluj, Târnăveni as well as three from the by then Romanian province of 3 în Bessarabia (Chişinău, Tighina and Cetatea de Baltă); they have been quick indeed to respectively earn the economical independence and the professional prestige they beyond any doubt deserved. Their issued wines have ultimately come to be fully appreciated by the most exigent among the Romanian consumers as well as by the foreign people who were visiting our country. The later 
achieved exportation of the Romanian high quality wines could already be foreseen on behalf of the above mentioned Wine-Making Cooperative. From 1924 until 1937 this type of associative forms have also and indeed provided to the whole of the Romanian wine-making profession a slightly increased amount of obtained financial profit. Yet at that time alike in our own days the success of such vine cultivating cooperatives had been necessarily conditioned; honest and professionally devoted people had to be chosen in order to guide them so that their respective assumed authority and accumulated experience could effectively determine the concerned real estate owners to trust them without in no way having suspicious thoughts in respect to their activity and good intentions. Let us then present as an illustrative and referential example the "Drăgăşani” vine cultivation cooperative. Its activity had begun in 1929 when it had gathered a number of 143 associates who had subscribed on its behalf a total and liquid capital sum of 1244000 lei. The appropriate building where the grapes could be stored and conditioned so that they should further undergo the subsequent wine-making process had then been bought from the Wines Trading Society Drăgăşani through a contracted lawn at the Central Cooperative Bank which had been pledged for by the Romanian Ministry of Agriculture and of Domains. The above mentioned building had an effective storage capacity of 1600000 litres, it was duly endowed with all of the necessary recipients and technical mechanisms and its total cost had been the one of 7800000 lei (Gh. Roşescu, 1943). This cooperative did take a really hard time and had to make great efforts in order to overcome the effects brought in by the worldwide financial crisis but it was yet rather quick to recover from it. After having crossed these bad times the Ministry of Agriculture and of Domains had prepared for it a carefully elaborated plan through which it had become a regional collecting center dedicated to the purpose of obtaining high quality wines in accordance with the vine kinds which the Direction for Vine Cultivation within the Ministry had previously decided upon as being the most suitable for the Drăgăşani region. In each of its communes a center had been created through which they could continuously keep in touch with Drăgăşani and a local commodity exchange office for wines had as well been instituted. Tight connections are also created with some retail trade consumption cooperatives so that the wine production could be traded in accordance with the prior established strategy. As immediate annexes to the cooperative two specialized schools had been also founded: one for the training of master cellarmen and the other for the training of some scientifically qualified vine cultivators. The syndicates by then active in the vine cultivation domain did as well hold an important part in scientifically guiding and also defending the legal rights of the small-sized private wine-makers. For example let us take a look at the seed bed nurseries domain for which their respective syndicates had chosen as objectives to be realized: - a rational approach to be chosen towards the logs production; - to appropriately defend the common interests of the associated seed bed nurseries owners; - to dedicate a minutious study to the vine cultivation issues which used to arise within the vineyards; - to promote and support the vine re-planting procedures for the eventually deserted plots from within the vine cultivation zones; - to ease the needed supplies in logs to be engrafted and in their respectively pendant engraft strings; - for each private individual vine cultivator the choice to be made of at most three vine kinds to be engrafted; -to most accurately establish the basic elements of the scientifically correct technology through which the vine planting material could be produced; - to watch over the quality performance of the vine cultivation agricultural works; - to 
exactly establish the most appropriate beginning date for the vine engrafting and respectively forced growth technical procedures; - to choose the best suitable land plots; - to organize common retail trading operations; - to organize some excellence level training courses in vine cultivation and in wine-making for the associates; - to closely collaborate with the agriculturally profiled organs and institutions of the state).

On the eve of 1930 the structure held by the vine plantations in Romania had been the following:

- plantations made of engrafted logs - 123875 ha of which: plantations made of indigenous logs (rooted by their own) - 36437 ha;

- $\quad$ plantations made of directly productive hybrids - 167624 ha;

- $\quad$ plantations made of engraft-bearing logs - 483 ha;

Total: 328417 ha

We are therefore entitled to ascertain the fact that after 1921 the Romanian vine cultivation patrimony had known an obvious development process. Yet we do also consider ourselves as due to point out the real and exactly described status by then held by the above mentioned vine plantations.

- The most exquisite wines had been offered by the surfaces planted with both by themselves noble and engrafted logs in respect to which the greatest financial investments had until that time been done in Romania. It is of those vineyards that the pride of our country was the highest and about which we did feel morally embellished. Our most precious trade practices did rely upon them and they were as well comforting our hope for being able to develop in the future an exportation trade of grapes and wine;

- At that time the noble indigenous vine logs rooted on their own could only be found within the plots which had not been affected by the phylloxera that is to say upon sands;

- Yet the great mass of the small and private peasant vineyards which most of them had been planted after the Agrarian Reform had been constituted out of directly productive hybrids the respectively offered products of which had indeed an absolutely inferior level of quality. However this type of plantations had by then grown to an unprecedented extent upon the plain fields since 6000 till 7000 ha had come to be annually planted (Viala P., 1926);

- In spite of this fact the seed bed nursery owners did dispose of the required material for the most suitable engrafting of the above mentioned noble vine logs that had resisted to the phylloxera through the plantations made especially of logs destined to bear growing engrafts.

At that time the respective proportions held by the vineyards made of directly productive hybrids within the most important among the vine cultivating countries (Zweigelt F., 1929) did demonstrate the highly pernicious extent they had eventually come to acquire within our country: Romania 40\%; Yugoslavia 33\%; Russia 10\%; Ungaria 5\%; Tchecoslovakia 3,8\%; Bulgaria 3\%; Austria 1,5\%; France 1,5\%; Germany $1 \%$.

Since by misfortune we had been that abundantly endowed with directly productive hybrids the vine cultivation practice in Romania could in no way at all become profitable. This is the reason why the decision making organs of the state had obviously tried their best in order to stop their proliferation. As a consequence on June 26-th 1930 a law had been enforced the aim of which had been to stop the private vineyards from being planted with directly productive hybrids. Their surface did thus begin to diminish but yet through a so slow rythm that even after a hundred 
years have passed we still have about 80000 ha of them planted. (Nicolae Constantinescu, 1932; Popa A. and coll., 2017). research.

2. Actions taken in the respective domains of academic training and scientific

In 1924 - due to the initiative taken by Professor Alexandru Zaharia - in the frame of the Faculty of Sciences from Bucharest the first ever Romanian Institute of Agricultural and Alimentary Chemistry had been founded where its creator had as well gathered a pretty well supplied library specialized within the domain of general chemistry but most of all within the ones of the alimentary and agricultural respective industries. In 1928 through another enforced law the Superior School from Herăstrău and the Academy from Cluj are legally reunited and transformed into the Academy of High Agronomic Sciences. In-between the two World Wars the School of Horticulture from Bucharest had functioned in order to train the medium range staff while for the promotion of the adjacent staff seven vine cultivation schools had functioned throughout our country among which let us mention the ones from Miniş, Odobeşti, Huşi, Valea Călugărească etc.
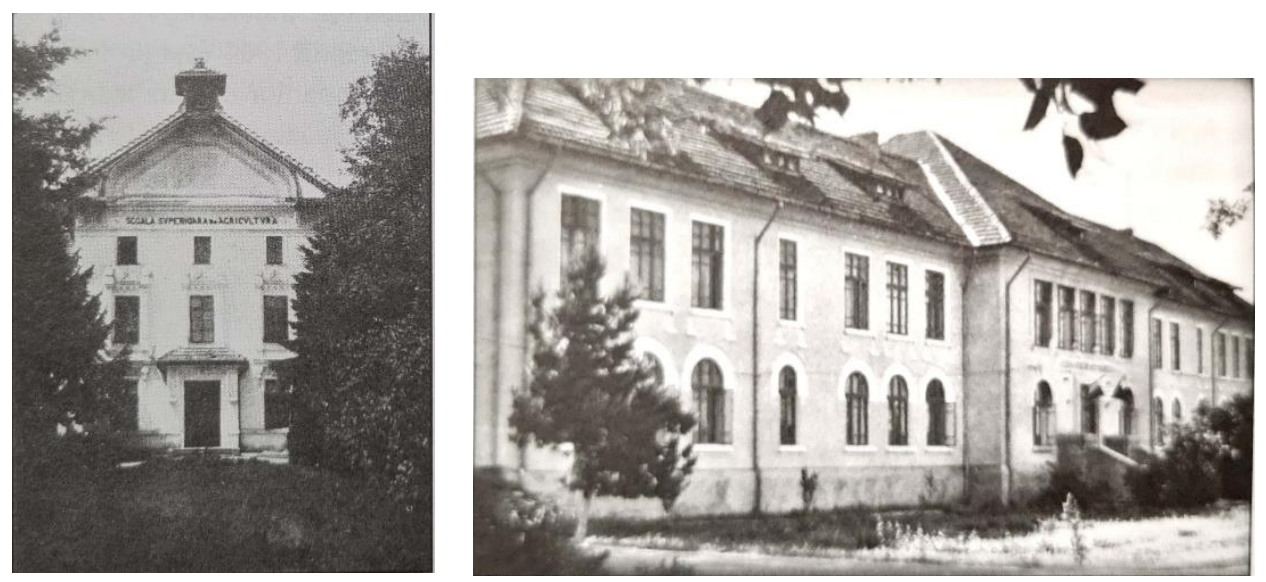

Building where the Superior School of Agriculture Main building

at the Viticultural School of Valea Călugărească once located in the Herăstrău Park has functioned

Around 1929 the above mentioned thirteen vine cultivation schools had indeed come to assume a decisive part in the dissemination of the specialized scientific knowledge among the private individual cultivators but they have as well participated in the research activities and in the ones related to the production of the most suitable planting material. 

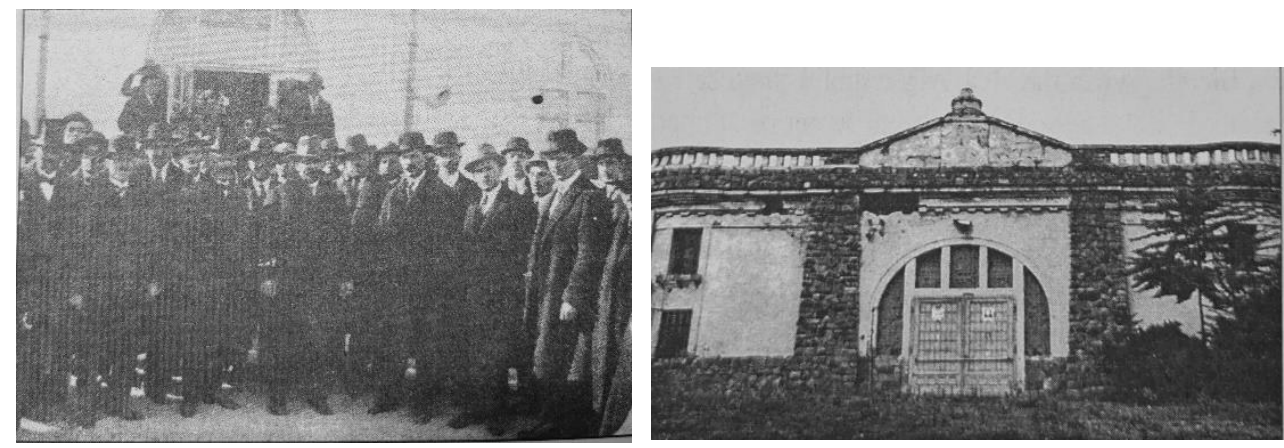

Press House-Wine Cellar-Wines'Collection at the Viticulture School of Huşi Inauguration of the Viticultural School of Huşi (on October 26-th 1924) (where Gh. Ionescu-Siseşti, Ernest Grinţescu and I.C. Teodorescu do figure among the participating persons)
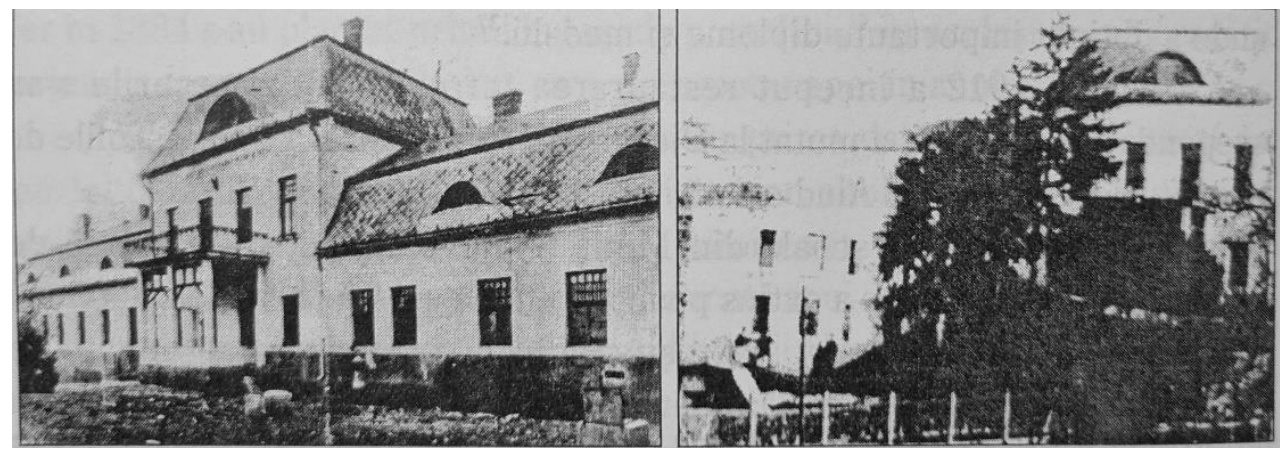

Viticulture School of Miniş (1914)

In 1928 - due to the initiative taken by Professor Gheorghe lonescu Siseşti - the Romanian Institute of Agronomic Researches had been founded and further led by its founding father untiil 1948. In 1920 the Agronomic Station from Bucharest is also founded; at first it had been guided by I. Enescu (1920-1929) then by Professor I.M. Dobrescu (1929-1933). At first it had been included within the frame of the R.I.A.R. under the denomination of Central Agronomic Station while in 1933 it had been turned into a Chemistry\&Oenology Station. In 1930 the Chemistry Station from Cluj is as well included to the frame of the R.I.A.R. under the denomination of Agronomic Chemistry Station and placed under the guidance of Professor Mircea V. lonescu; it had continued to function until 1948 when its activity had ceased.

In his official quality of Inspector of the Vine Cultivation Schools and of the State's Vine Seed Bed Nurseries Professor I.C. Teodorescu had formulated the proposal of transforming the seed bed nursery from Pietroassa into an experimental station for vine cultivation and oenology; or Professor Gheorghe lonescu Siseşti who at that moment was the general director for the agricultural academic training within the Ministry of Agriculture did happen to agree with and to sustain the above mentioned suggestion so he eventually had obtained its approval from the minister in person who did also decide to designate Professor I.C. Teodorescu himself as the first director of this newly created institution (1922). In this newly established official quality he then had founded at Pietroassa the first ever Romanian experimental vine 
plantation for competitive purposes; it had been constituted of twelve fruit-bearing Romanian vine kinds and twelve foreign wine-making vine kinds; each among these twenty-four vine kinds had as well been engrafted upon ten engraft-bearing vine logs. Together with the Seed Bed Nursery from Istriţa the Pietroassa Station had effectively become the material ground made use of for performing its scientific experiments by the Chair of Viticulture and Oenology within the Academy of Agronomic sciences from Bucharest as well as a center of practical training for its students. Within the time interval going from 1927 till 1930 due to the initiative taken by the Direction for Vine Cultivation within the Ministry of Agriculture eight experimental vine plantations had been respectively established at Cotnari, Odobeşti, Valea Călugărească, Pietroasa, Murfatlar, Drăgăşani, Miniş and Diosig. Within these vine cultivation centers and through a collaboration started with the Romanian Institute of Geology - the designated representative of which had been $\mathrm{N}$. Cernescu - some scientific investigations concerning the respective natures and compositions of the encountered types of soils had also been initiated. In 1928 had been as well founded at Pietroassa, Drăgăşani, Valea Călugărească and Miniş the first ever Romanian meteorological stations made use of in order to study the climate's occurring phenomena; from them understood as a starting point a whole network had afterwards come to be created which used to serve as the technical ground for most effectively organizing the occurring blight alerts.
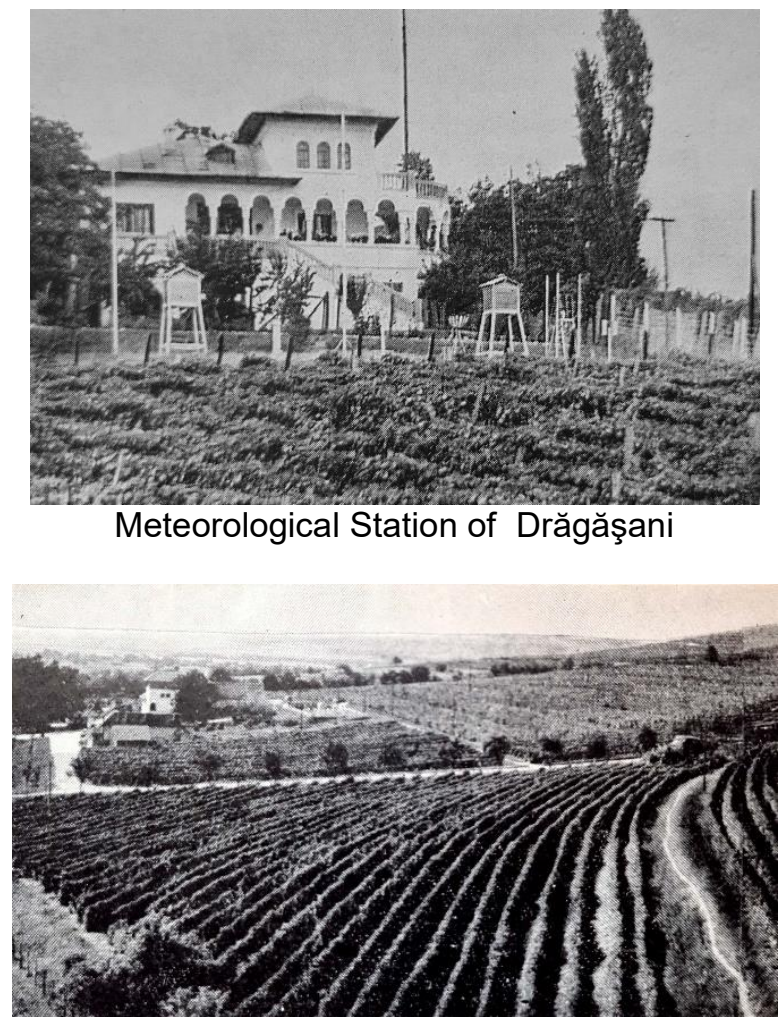

Ampelography collection located at the Station for Viticulture and Oenology of Drăgăşani 
During this above mentioned period the scientific activity which was carried on in the oenology domain had been mainly and mostly developed at the Agronomic Station in Bucharest, the Agronomic Chemistry Station in Cluj and at the Chair of Viticulture and Oenology from the Academy of High Agronomic Studies in Bucharest. As the Romanian vine cultivation and wine-making practices were passing in this time interval through the hard circumstances we have outlined above this scientific activity could indeed take a most important part through participating in their respective restoration and further development processes. It has been fulfilled simultaneously and has been most harmoniously mingled with the technical, scientific and administrative activities that had been initiated by the Ministry of Agriculture through the actions taken by its Direction for Viticulture and Horticulture.
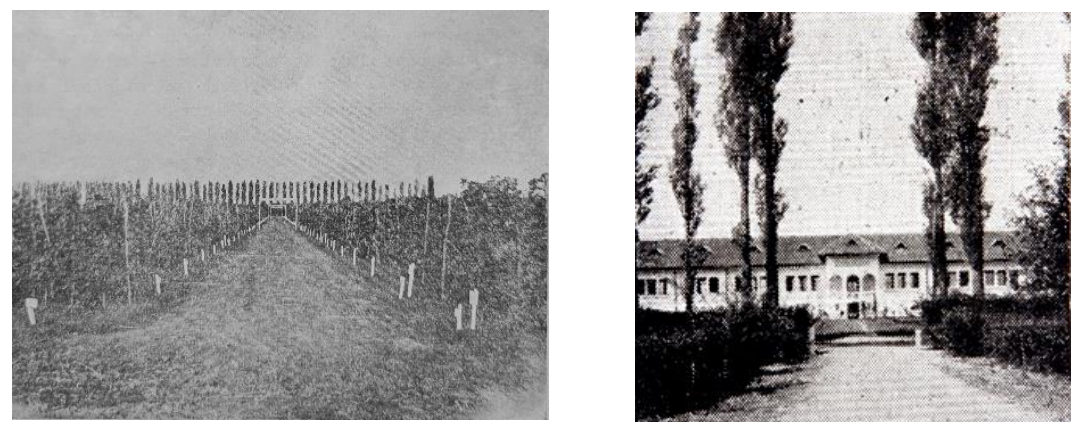

Land plot dedicated to studies in ampelography which do concern

Complex Laboratory for vine plants'grafting and quickened

the d.p.h.at the seed bed nursery of Istriţa-Buzău

growth at the viticulture seed bed nursery of Drăgăşani (1923)

Should we look at it from the respective points of view of its nature and contents we would be able to ascertain the fact that the scientific activity performed during this time interval had been simultaneously accomplished within three distinct and yet parallel dimensions: the first one has been focused upon the continuation and further extension of the activity consisting in the always deepened study of the wine's chemical composition carried on for the purpose of effectively protecting its natural inner assets and its quality level; the second dimension had been a rather new one the activity of which had been related to the micro-biological stratum held by the wine and was pursued in order to improve for the best its quality; as for the third one it was dedicated to the beginnings of an accurately elaborated outline of the scientific investigations to be carried on about the most efficient technologies to be applied throughout the creation and respectively conditioning processes which should be necessarily undergone by the wine. The results obtained through the above mentioned scientific research activities had thus been brought to the public knowledge through the:

- annual publishing (from 1920 till 1928) of many studies and memoirs which discussed of the respective chemical compositions and quality levels held by the grapes and wines issued from various vine kinds as well as from most of the Romanian vine cultivating regions. şi dărilor de seamă asupra compoziţiei chimice şi calităţii strugurilor şi vinurilor din diferite soiuri şi din majoritatea regiunilor viticole ale României. Together with a lot of scientifically renowned collaborators I.H. Colţescu had published as the main and coordinating author the treatise: „Studiul 
compoziţiei vinurilor din România" [Study on the composition of the wines from Romania] (1929);

- the same I.H. Colţescu had founded in 1928 - for the first time ever within the vine cultivators world - the "Cazierul vinurilor" [Wines'Identification Record] the purpose of which was the one to annually record the physical, chemical and empirically sensible features of the wines which could be obtained through the separately distinct wine-making process undergone by the grapes from each of the cultivated vine kinds except for the ones which only produced table grapes. These operations had been carried on for each of the Romanian vine cultivating regions and had been further divided into distinct centers and realms;

- scientific information had been gathered insofar the respective behaviors and owned inner values of the hundreds of vine kinds which at that time were cultivated on the territory of our country could be concerned and this scientific enterprise had later allowed the Romanian specialists to precisely identify and limit to it (50) the number of vine kinds which deserved indeed to be multiplied within the seed bed nurseries and further cultivated within our suitable regions (Constantinescu Gherasim, 1945);

- at Valea Călugărească in 1929 the first ever exposition of table grapes as well as the first ever scientifically specialized competition among wines had been organized in Romania;

- on the occasion to him provided by the works of the XIV-th International Agriculture Congress held in Bucharest (1929) Professor I.C. Teodorescu had presented his treatise "Viile României” [The vineyards of Romania]. It is a monograph-type study dedicated to the geographical aspects which could be related to the vine cultivation process as well as to a comparative approach towards it;

- during the same year 1929 Professor I.C. Teodorescu had presented on the occasion to him provided by the works of the I.V.W.O. Congress then held in Barcelona the national report from Romania: „La répartition des vignobles roumains en groupes naturels" [The distribution of the Romanian vineyards into naturally justified groups] also supported by a Romanian map of the existing soil profiles brought in as an attesting evidence exhibit (Bull. OIV., Nr.19/December 1929);

- at the International Conference on Wine held in Paris (1932) I.C. Teodorescu and I.H. Colţescu have presented the vine cultivation and oenological map of Romania which they had elaborated themselves and which had been printed for this occasion by the Ministry of Agriculture through its Cadastral Survey Direction;

- From 1932 until 1936 had been delimited and legally enforced in Romania the first ever vine cultivated areas that had been entitled to bear a controlled origin denomination that is to say: Buzău, Cotnari, Dealul Mare, Drăgăşani, Murfatlar, Nicoreşti, Odobeşti, Panciu, Sadova, Sarica, Segarcea, Turnu Severin (within the ancient kingdom); Alba lulia, Bacova, Diciu-San, Martin, Diosig, Gherteniş, Mediaş, Miniş, Mureş, Năsăud, Silagiu, Tomnatic, Telna, Teremia (for Transylvania and for Banat). Those controlled origin denominations had been awarded in the virtue of the newly enforced law for the defense of the vine cultivation practice from 1936;

- in 1928 Romania had ratified its adhesion to the I.V.W.O. so it had become entitled to send a member to siege within its Direction Committee (embodied through the living individual person of Eng. Romulus Odobeşteanu);

- within the session of the I.V.W.O from December 1928 the assembly had been satisfied to become aware of the fact that in Romania - as in France and in Spain too - the syndicates and professional associations which were activating 
within the domains of vine cultivation and of wine-making are legally entitled to constitute themselves as civil sides in all of the fraud cases and to designate on their own behalf some empowered investigators who should stand as witnesses in order to denounce the proven frauds perpetrated within the vine cultivation and winemaking related matters;

- at the I.V.W.O. reunion of December 1928 its Director mentioned the support he had received from the medical most renowned scholars as well as from the other most recognized scientists of other domains from Spain, France, Hungary, Luxembourg, Romania through the edifying works which had been presented at this reunion insofar the alimentary and respectively hygienic values held by the wine could be concerned; those works could therefore be forwarded as a judicious argument line through which should be rejected the opinions which had previously been expressed within the frame of the General Assembly of the Nations League held in Geneva and through which the prohibition of wine had been requested;

- since 1925 Professor I.C. Teodorescu had laid at the Academy of High Agronomic Studies from Bucharest the grounds of the first ever Romanian great ampelographic collection of fruit-bearing vine kinds - should they be either indigenous or foreign ones - which had been each of them engrafted upon five different kinds of engraft-bearing vine plants; a collction had as well been constituted which did gather both pure kinds and hybrids of engraft-bearing vine plants out of which later could be disseminated a lot of other kindred collections destined to be made use of by the vine cultivation schools and by the experimental stations throughout the country;

- As an answer given to the many times iterated proposals coming from its Viticulture Direction in 1930 had been founded at the request of the Ministry of Agriculture the State Monopoly on Alcohol and Consumption Taxes; the pursued aim had been the one that this new institution should be obliged to transfer towards the Ministry of Agriculture a certain previously established percentage of its obtained income. Those sums of money had to be made use of in order to restore and develop the current horticultural practice. This had been indeed the legal procedure through which the Viticulture Pavillon has been built and endowed at the Academy of High Agronomic Studies in Bucharest. This is as well the way through which the Pietroassa station had come to build and adequately endow its main location which contained the laboratories, the press house and the cellar. Orchard areas planted with fruit-bearing trees had been also founded and for example at Istriţa or PopeştiLeordeni the first ever Romanian industrial fruit processing units had been established. A lot of young and talentuous engineers are thus sent for attending specialized study courses in France, Germany, Austria or in the United States of America (Cătălin Golan, 2005);

- Since he had relied upon the conclusions he had drawn from the documentary and comparative study he had performed during several years (from 1919 till 1922) upon the respective viticultural behavior, productive capacities, chemical compositions and quality levels reached to by grapes and by their issued wines in the cases of 120 varieties of directly productive hybrids which he had found in some important Romanian collections Professor I.C. Teodorescu had taken advantage from the occasion to him provided by the International Conference on Wine held in Paris (1932) in order to urgently warn against the danger represented in the vine cultivation practice by the directly productive hybrids. It had been for the first time ever that such an attitude had been assumed within the works of an 
international specialized forum. It had as well been presented under a written form through the Romanian elaborated report. Of course violent protests had then risen from many among the hybrids creators who then were present in the audience but the conclusion finally drawn from these stormy debates had confirmed the just opinion which had been held and sustained by the Romanian delegate. The Romanian vine cultivators had ultimately earned a prestige success (Nicolae Ştefan and coll., 2008);

- In 1936 had been enforced the Law for the defense of viticultural practice. Through the motivations exhibit of this law the mistakes that had been done within the Romanian vine cultivation practice after the phylloxera invasion had been accurately evoked: - the ancient sorts of vine kinds which were intrinsic to our regions had been abandoned with no serious reasons at all that could justify this desertion; - the further and scientifically not justified extension of vineyards into the former agricultural plain zone; - the hugely extended culture of the directly productive hybrid logs the ratio of which had come to quantitatively exceed by far the cultures of the engrafted logs situated upon hillocks or the ones of the indigenous vine logs which had come to survive out of the phylloxera massacre as being planted upon sands; the substitution of the vinegar obtained from wine or fruits by the industrially obtained acetic acid - that is to say through the distillation of wood - which at that time had been deceitfully denominated as "vinegar essence”.

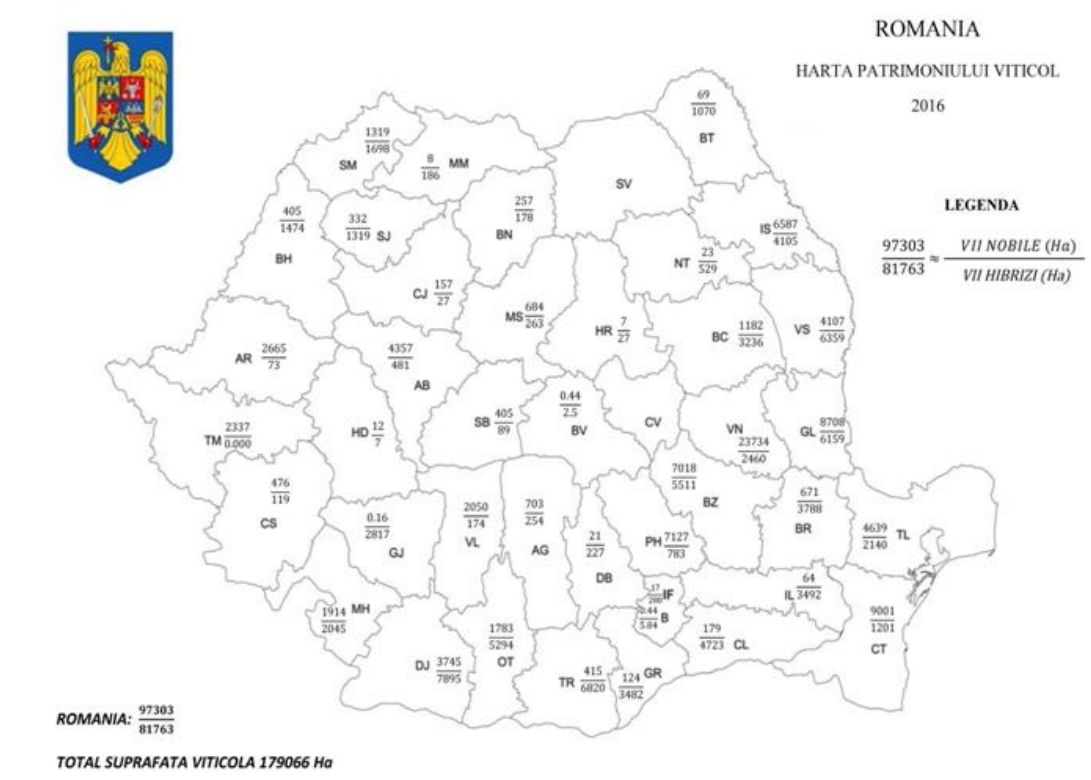

Surfaces of the Romanian fruit-bearing vineyards respectively classified by departments (2016). Total vine cultivated surface.

The eventually tragical circumstances undergone by the Romanian vine cultivation practice had been finally and fully exposed: „wine has become cheaper than soda” while „an empty barrel is two or three times more expensive than the wine it does contain”; "the price which could be obtained for ten litres of wine is equal to the taxes that ought to be paid for this quantity towards the department and the 
commune"; "the price of the performed vineyard's labour (40 lei/day) is more expensive than the value held by the produced wine itself (10-12 lei/dal)”; „one third among the vineyards had remained unlaboured since many of the wine-makers have chosen to bury the vine bushes with their grapes on" etc.

The above mentioned law did contain stipulations which indeed concerned each of the aspects related to the culture of vine and to the wine-making process; there are many among them which are still valid even in our own days. The Law on stopping the vine plantations with directly productive hybrids - the planting of hybrids had become prohibited! - had been enforced on June 26-th 1930. As its direct consequence their extension had been more or less stopped. Yet as a matter of fact even in our own days we do find ourselves confronted with a similar plague - which by now is almost reaching for the same level as the one recorded during the time interval from 1924 till 1937.

For the time period immediately after the Agrarian Reform of 1921 we are due to mention the respective issues of many specialized publications - all of them aiming to support the restoration, development and modernizing of the vine cultivation practice in Romania. Among them the most prestigious journal had been „România Viticolă” [Vine cultivating Romania]. The first ever scientific research Stations dedicated to the disciplines of vine cultivation and oenology are founded: 1936 in Drăgăşani and in Odobeşti; 1940 in Murfatlar; 1949 in the locality of Crăciunel.
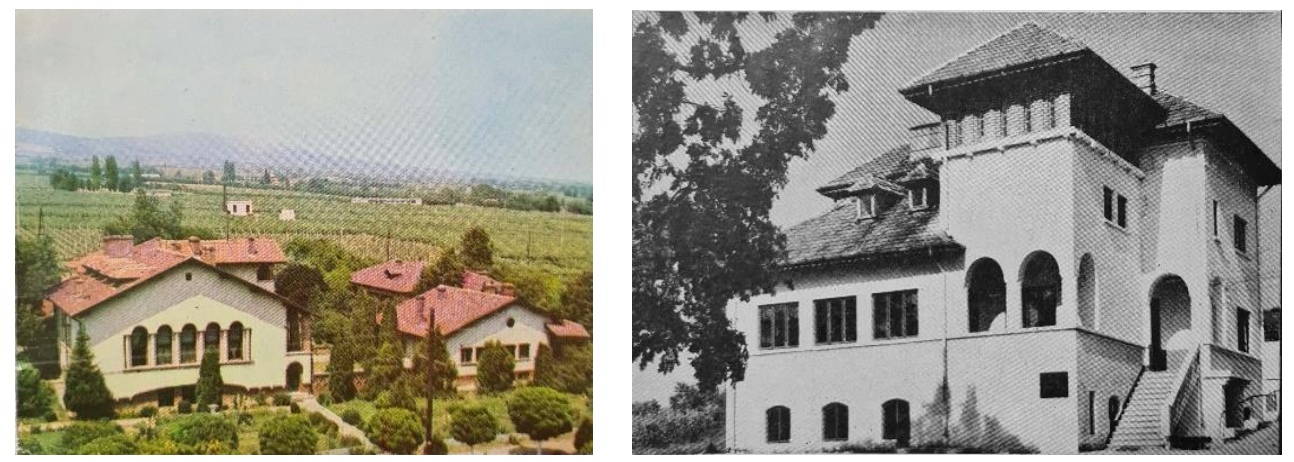

Main building of the Station for Viticulture and Oenology

Main building of the Station for Viticulture and Oenology in Drăgăşani (1936) in Odobeşti (1936)

In 1942 Professor I.C. Teodorescu together with other collaborators who were by then acknowledged personalities within our scientific discipline did publish the treatise "Viile experimentale din România" [The experimental vineyards from Romania]. Within it they did present the obtained results which had been respectively reported by the vine cultivation schools, vine seed bed nurseries or experimental Stations focused on vine cultivation and oenology located within eleven regions or centers. The specialists from the Viticulture Section within the Ministry of Agriculture as well as the ones from the R.I.A.R.'s Chemistry\&Oenology Station had performed some highly important field studies within the Alba lulia vine cultivating region and through the intermediary of the journal „România viticolă” in 1946 they had consequently come to publish the resulted highly valuable monograph work 
„Podgoria Alba lulia” [The Alba Iulia Vineyard]. On the occasion provided by the inauguration of the building which hosted the laboratories from the de la Station for Vine Cultivation and Oenology in Drăgăşani the monograph „Podgoria Drăgăşani” [The Drãgãshani Vineyard] had appeared. Let us otherwise point out the contents of a few among the studies carried on and published by Professor I.C. Teodorescu at the Viticulture Chair within the Academy of High Agronomic Studies in Bucharest because these studies have raised an intensive interest as well from the private vine cultivators as from the decision making public servants who had been active in office at that time:

- Through a comparative study performed at the Pietroassa experimental vineyard upon twenty-two Romanian varieties and upon eight foreign ones insofar respectively the oenological assets of the grapes, their mechanical strength and their fundamental chemical composition could be concerned in 1929 Professor Teodorescu has been able to scientifically demonstrate the inner productive potential owned by the indigenous Romanian vine logs;

- Various well-known personalities as well as the common people themselves have openly expressed their appreciative opinions honoring the Romanian wines;

- Professor Teodorescu had as well minutiously described the distinctive and constant type-casting of the Romanian wines created within various regions as it had throughout time resulted from the wished for syntheses elaborated among the ancient and famous sorts of vine kinds within his work published in 1925 "Caracterizarea diferitelor podgorii ale României" [Characterization of the various vineyards of Romania];

- The various methods through which wine could be created and further conditioned as they had been traditionally conceived by the ancient Egyptian, Jewish, Hellenic and Roman peoples as well as the current requirements which at that time did involve the above mentioned matters had been exposed in 1926 by Professor Teodorescu through his work "Condiţionarea vinului pentru marele comert de export" [The wine's conditioning for the great exportation trade];

- He had minutiously described the wines and the sorts of vine kinds issued from the Romanian province of Moldavia through his work published in 1948 „Perlele Moldovei - Cotnari şi Uricani" [The Pearls of Moldavia - Cotnari and Uricani];

- He had also established the competitive classification norms and decided upon the final results obtained at the grapes Exposition and at the subsequent wines contest that had been organized in Valea Călugărească (1928);

- He had discussed about the most effective opportunities, development actions to be taken, parts to be respectively assumed within this process by the Romanian state as well as by the individual wine-makers within his work „Exportul strugurilor şi vinurilor româneşti” [The exportation of the Romanian grapes and wines] (1928). In the Cişmigiu Park of Bucharest the first Romanian therapeutical station providing a medical treatment through the consumption of grapes and of must had been inaugurated in 1932 under the guidance of a medical doctor. In his assumed quality of Director of the Chemistry\& Oenology Station a micro-biologist Professor Ernest Russ had for the first time ever in our country perfected the made use of technique as well as the most appropriate modality through which could be organized the multiplication process and the further delivery within phials of the 
cultures of pure yeasts (1920-1927). He has thus been an active pioneer insofar their dissemination among the individual and private wine-makers whom he has convinced to apply them while elaborating the wines respective chemical compositions. Simultaneously he had studied the micro-flora of the ill wines and he had also published many works on the possible causes of their acquired illnesses, the ways to strive against them and the modalities through which they could be prevented. He had as well published the first ever treatise concerning the wines micro-biology issued in Romania. In the frame of the R.I.A.R. the above mentioned Chemistry\&Oenology Station through its laboratory focused upon the wines technology and guided by Professor Ştefan Teodorescu had created some tight relationships as well with the wine producers as with its traders in order to support them all in their respectively carried on processes of creating and conditioning the wines. Within this laboratory had been initiated the first ever Romanian scientific researches which did concern the wines elaboration and conditioning respective processes performed through both physical and chemical modalities which could provide for the concerned wine the sought for stability of its health and clearness. Of course in Romania had also been carried on many other scientific investigations which had brought a significant support to the native vine cultivators and to which the other vine cultivating countries had paid a well-deserved attention by carefully taking them into an effective consideration.

\section{CONCLUSIONS}

1. After the agrarian reform enforced in 1921 in our country the vine cultivation practice had to undergo a new stage which consisted in the necessary processes of restoration, development and modernizing. They had been required due to three most pernicious reasons: the disaster caused by the phylloxera attack to which had come to join the effects of the worldwide economical crisis (1929-1933) under the local circumstances when in Romania the legally enforced structure of the real estate ownership had as well come to pass through an essential modification;

2. During this time interval have been founded several institutes and units profiled on academic training and on scientific research which through their respectively performed activities had indeed brought a considerable contribution to the restoration and development of the national vine cultivation patrimony;

3. Great efforts had been achieved in order to fulfill the purpose of effectively disseminating the proven scientific knowledge of that time concerning the vine cultivation process as well as the newest work applicable modalities throughout the mass of private individual vine cultivators;

4. We are due to remark the existence of the similitude and synchronization respective phenomena insofar could be concerned the sense and the chosen objectives of the actions taken at that time by the academic training staff, the researching scientists and the administrative organs of the state;

5. An important number of specialists have at that time acquired a most judicious academic training formation as they had been gathered around a few prominent Romanian personalities of our domain;

6 . Within a relatively brief time interval (1921-1930) in Romania the vine cultivated surface had considerably increased; 
7. Yet we are due to also point out the fact that during the same period of time the vine cultivation process carried on in Romania had still been seriously affected by three great commonly perpetrated mistakes: a. the miscalculated and disordered reconstruction attempts; b. the perpetrated falsifications; c. the catastrophic extension unfortunately achieved by the directly productive hybrids. Due to these circumstances the vine cultivation process as a whole had come to be compromised not only through its functional structure but as well within its daily economical efficiency. As a consequence the Romanians had been empeached from gaining whatever profit from the great treasure which is genuinely constituted by our indigenous vine kinds and their respectively issued wines;

8. Many among the scientific and organisational actions which had been taken during that time period have come to prove themselves as very useful until our own days and had also been recognized as much valuable turning point initiatives by other vine cultivating countries throughout the world;

9. To its great honor we are due to say that on this above mentioned occasion as well science has much quickly and skilfully made it in solving all of the problems that had risen in front of it insofar the national vine cultivation patrimony could have been concerned since it had successfully achieved the restoration and development processes it necessarily required; as a matter of fact we are glad to state that even its modernizing process had by then begun.

\section{REFERENCES}

Berger C. Plaiul viilor, Dealul Robului din Segarcea-Dolj; 1946; Rev. România Viticolă, Anul X, Nr. 4-6; Bucureşti.

Gherasim C. 1939. Excursia viticolă a absolvenţilor Academiei de Înalte Studii Agronomice din Bucureşti la Topoloveni, Florica şi Drăgăşani; Rev. România Viticolă, Anul II, Nr. 10; Bucureşti.

Gherasim C. 1945. Problema sortimentelor în viticultură şi represiunile ce le exercită asupra comerţului de vinuri; Rev. România Viticolă, Anul IX, Nr. 1-3; Bucureşti.

Galan C. 2005. Scurt istoric de legislaţie agro-viticolă românească; Teză de Doctorat USAMV Bucureşti.

Constantinov N. 1932. Problema Hibrizilor Producători Direcţi în România; Imprimeria Naţională Bucureşti;

Ştefan N., Glăman Gh.; Oşlobeanu M., Pomohaci N., Popescu V., Rusu C.; 2008. Horticultura României de-a lungul timpului; Vol. II; Ed. Academiei Române Bucureşti.

Popa A. 2014. Repere Oenologice Româneşti (secolul XX); Ed. Alma Craiova;

Popa A, Dicu Cornel. 2010. Viticultura şi Vinurile României; Ed. Alma Craiova;

Roşescu Gh. 1943. Monografia Cooperativei Viticole Drăgăşani; Rev. România Viticolă, Nr. 9; Bucureşti.

Teodorescu C.I.. 1939. Tratat de viticultură. Manuscris.

Teodorescu C.I.; 1934. Patrimoniul viticol al României; Tipografia „Ion C. Văcărescu, Bucureşti.

Teodorescu C.I. 1939. Viticultura şi cooperaţia; Rev. România Viticolă, Anul II, Nr. 10, Bucureşti. 
Teodorescu Ştefan, Popa A., Sandu Gh.; 1987; Oenoclimatul României; Ed. Ştiinţifică şi Enciclopedică, Bucureşti.

Viala P. 1926. Revue de viticulture; Nr. 1607/26 mai, Paris.

Zweigelt F.; 1929. Die Direktträger, pg. 381. 